1979

\title{
Phase II Archaeological Investigations along the Proposed Route of the Del Norte Pipeline
}

Thomas C. Kelly

Thomas R. Hester

Center for Archaeological Research

Follow this and additional works at: https://scholarworks.sfasu.edu/ita

Part of the American Material Culture Commons, Archaeological Anthropology Commons, Environmental Studies Commons, Other American Studies Commons, Other Arts and Humanities Commons, Other History of Art, Architecture, and Archaeology Commons, and the United States History Commons

Tell us how this article helped you.

This Article is brought to you for free and open access by the Center for Regional Heritage Research at SFA ScholarWorks. It has been accepted for inclusion in Index of Texas Archaeology: Open Access Gray Literature from the Lone Star State by an authorized editor of SFA ScholarWorks. For more information, please contact cdsscholarworks@sfasu.edu. 
Phase II Archaeological Investigations along the Proposed Route of the Del Norte Pipeline

\section{Creative Commons License}

(c) (1) (9)

This work is licensed under a Creative Commons Attribution-NonCommercial 4.0 International License 
PHASE $\|$ ARCHAEOLOGICAL INVESTIGATIONS

ALONG THE PROPOSED ROUTE OF THE DEL NORTE PIPELINE

Thomas C. Kelly and Thomas R. Hester

Center for Archaeological Research The University of Texas at San Antonio Archaeological Survey Report, No. 74

1979

Photocopy Reprint

1982 
PHASE II ARCHAEOLOGICAL INVESTIGATIONS

ALONG THE PROPOSED ROUTE OF THE DEL NORTE PIPELINE

Thomas C. Kelly and Thomas R. Hester

Center for Archaeological Research

The University of Texas at San Antonio

San Antonio, Texas 78285

Center for Archaeological Research

The University of Texas at San Antonio

Archaeological Survey Report, No. 74 
TABLE OF CONTENTS

Page

List of Figures and Tables.................. ii

Acknowledgments ....................... ii

Introduction ........................... 1

Goals of Phase II ................. 1

Survey Procedures .................... 2

Survey Results . . . . . . . . . . . . . . . 2

Summary of Survey Results . . . . . . . . . . . . 20

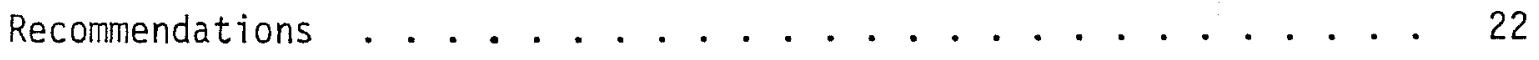

References cited ................... 23

$i$ 


\section{LIST OF FIGURES AND TABLES}

Figure

Page

1. MP 22.90 Tenneco A-38: Archaeological Zone . . . . . . . . 4

2. MP 31.66 Tenneco A-39: Archaeological Zone ......... 5

3. MP 42.15 Tenneco H-53: Historic Well ........... 6

4. Views of Historic Wel1, MP $42.15 \ldots . . . . . . .77$

5. Details of Well Tower Construction .......... 8

6. MP 133.4 Tenneco A-45: Banquete Creek Archaeological Zone

and MP 134.15 Tenneco A-46: Prehistoric Site and Potential Zone. . 11

7. MP 141.08 Tenneco A-47 (41 NU 171): Prehistoric Site ...... 13

8. MP 184.19 Tenneco A-48 (41 RF 16): West Fork of Melon Creek . . 15

9. MP 191.58 Tenneco A-49: Western Edge of Sharps Lake and MP 192.70

(41 RF 12) Tenneco A-36: Sharps Lake Prehistoric Site.... . 17

10. MP 192.70 Sharps Lake Prehistoric Site . . . . . . . . . 18

11. MP 200.43 Tenneco H-50: the De La Garza Homestead . . . . . . . 19

Table

1. Phase II Prehistoric and Historic Sites Along the Proposed

Pipeline Route ................... . 21 


\section{ACKNOWLEDGMENTS}

he cooperation of Tenneco personnel has been exemplary in the planning and execution of this project. We wish to especially thank the following people: 1. W. Patterson, R. P. Otjen, Jim Gault, Joe Gilliam, Tom Ellege, Cap Schubert, B. N. Duckett and Rube Coggins. 


\section{INTRODUCTION}

n Tate March 1978, Tennessee Gas Pipeline (Houston) authorized the Center for rchaeological Research, The University of Texas at San Antonio, to carry out phase II investigations along the proposed route of the Del Norte pipeline, outhern Texas. The Center had conducted an initial historical and archaeoTogical assessment of the pipeline route in 1977 and had recommended subsequent field work (Phase II) in order to better evaluate some of the findings made at that time (see Hester 1979).

The proposed pipeline route studied by the Center extends fron a point at the A io Grande near McAllen to Station 9, south of Victoria. A research plan for phase II historical and archaeological investigations along this route was cutritted to Tennessee Gas Pipeline by the Center.

\section{GOALS OF PHASE II}

Thase II research was designed to follow up on the findings and recommendacions resulting from Phase I (Hester 1979). Aside from specific recommencations in the Phase I report, we noted that several potentially critical ureas along the proposed pipeline route had not been examined on the ground cecause of either weather factors or poor surface visibility at the time. nus, our specific goals during the Phase II field work were:

1. Test excavations, several hand-dug units, either $1 \mathrm{~m}^{2}$ or $2 \mathrm{~m}^{2}$, at the Sharps Lake site (41 RF 12).

2. Intensive on-the-ground survey and possible test excavations (both shovel tests and controlled hand-dug units) in several different potentially sensitive zones, primarily in the 5 -acre blocks at stream crossings. If a site was identified and was evaluated as needing a testing program, such a program would be initiated by shovel tests to sample site depth and content, and would be followed by controlled hand-dug test units in order to obtain a better sample with which to judge impact of the pipeline on the site.

$\therefore$ Irtensive survey of certain portions of the right-of-way not previously examined in this manner. This procedure allowed site recognition and evaluation and could be accompanied by shovel tests and/or controlled hand-dug test units. This particular investigative goal was designed to permit examination of several pipeline areas that could not be examined during Phase I, due either to a lack of time or to extensive vegetative cover which prevented careful scrutiny of the ground surface.

Following the approval of our research plan by Tenneco Gas Pipeline, field rork was initiated. Thomas C. Kelly, Research Associate of the Center, directed field operations and was assisted by David 0. Ayers. The additional survey work described above was satisfactorily carried out and resulted in not only the better evaluation of Phase I data, but also in the additional recording of two historic and seven prehistoric sites (see "Survey Results" below). 
wever, the proposed testing program at the Sharps Lake prehistoric site enneco A-36, at MP 192.70) could not be carried out as planned. The landiner steadfastly refused to permit access to the property for the purposes archaeological research. After consultation with personnel of Tennessee a Pipeline, it was decided that the matter could not be pursued at the fesent time. The testing of the Sharps Lake site is an essential task that gmains to be done at some future date.

\section{SURVEY PROCEDURES}

fter consultation with Dr. Joel Gunn, The University of Texas at San Antonio, ie ruled out the use of statistical sampling techniques for the pipeline urvey. Mueller (1974:29-40) has summarized the problem of such sampling rocedures in this kind of survey: "Pipelines are not conducive to use of ampling theory because of following easily traversed terrain which is not epresentative of 211 environmental diversity within a naturally bounded region." We therefore decided to attempt $100 \%$ coverage, on foot, in a 11 mreas of the pipeline not covered in 1977.

Tre procedure followed was for one team member to start out walking, while the cther was carried by truck (along with our Tenneco guide) to a point three wiles along the right-of-way. The second team member walked from there while the truck waited until the first survey crew member arrived. They then drove to pick up the second team member. This "leap frog" operation surveyed about 25 miles of pipeline per day. The specified work-areas (5-acre blocks) at -ajor stream crossings were given complete coverage. Eolian and karst depressions and their attendant sand dunes were given detajled coverage, as these were expected to contain prehistoric camp sites, based on the predictions of 'dlouf, Baskin and Killen (1977).

The numbering of historical and archaeological sites began with Tenneco $\mathrm{H}-52$ ind $\hat{A}-37$, respectively, in continuation of the 1977 numbering sequences.

A1l sites found outside the 85-foot proposed pipeline right-of-way (hereafter abreviated ROW) were also fully recorded.

\section{SURVEY RESULTS}

Silepost

0 Recent survey markers for the proposed pipeline were located on the north bank of the Rio Grande. A strip approximately 50 meters wide between a farm road and the river is relatively undisturbed. It is mostly steeply cut banks covered with dense natural vegetation. This area was searched for 300 feet on either side of the pipeline marker. Frequent flooding may have eliminated a 11 archaeological evidence.

8.92 Winn Creek is typical of man's alteration of the area, having been completely straightened and deepened. Nothing was found. 
22.90 Tenneco A-38: Árchaeological Zone (Fig. T). MaiTouf, Baskin and

to Killen (1977) surveyed a $4-\mathrm{km}^{2}$ area which intersects the pipeline at

$24.20 \mathrm{MP} 22.90$ and is only 0.3 miles west of MP 24.20. Their intensive survey of this area produced four prehistoric sites, all badly disturbed, and only one (41 HG 38) identifiable to a cultural period (Late Prehistoric). The dunes at MP 22.90 in the ROW should have been high potential site areas, but no cultural evidence was found.

31.66 Tenneco A-39: Archaeological Zone (Fig. 2). Mallouf, Baskin and to Killen (1977) intensively surveyed another $4-\mathrm{km}^{2}$ area 0.9 miles east

33.20 of the ROW and found four prehistoric sites. Their Area 2 contained four completely destroyed prehistoric sites, and only one could be identified as a Late Prehistoric site based on arrow point typology. An extremely prolific site reported by Armando Vela (notes on file, Texas Archeological Research Laboratory, 1962) had disappeared without a trace. The pipeline crosses similar terrain with dunes and sinkholes, but no sites were found.

42.15 Tenneco H-53 (41 HG 51): Historic Well (Fig. 3). The site is 3.3 mites west, on the Santa Anita Ranch. We had heard during the Phase I survey of a hand-dug well that supposedly dated back to the 1790s, located somewhere in this area. Joe Gilliam, our Tenneco guide, was able to locate the well through local contacts. The well is located on the north edge of a circular and presently dry depression. It has interior dimensions of $6 \times 8 \mathrm{ft}$ with walls at the top uniformly $2 \mathrm{ft}$ thick. The well was lined with fairly small caliche rocks and cemented together with lime. Figure $4, b$ shows detail of its construction. It was abandoned long ago and present tenants of the ranch house (approximately 100 meters north of the well) use it for a rubbish dump. Fires have badly deteriorated the lower walls, and it is impossible, without excavation, to determine depth or age of the well. A tower was added to the north side of the well at a later date. This tower (Fig. 4,a) is $20 \mathrm{ft}$ tall, circular and $8 \mathrm{ft}$ in diameter at the top interior, with walls $2 \mathrm{ft}$ in thickness (see Fig. 5). The tower expands to $10 \mathrm{ft}$ interior diameter at ground level; there is a door with wooden lintels built on the east side, windows on the west and south sides. Crossbeams are set in the walls high in the interior, and all woodwork is pegged, with no nails anywhere. The exterior is covered with lime, and the areas around the west and south windows are heavily bullet-pocked, with many bullets remaining in place because of the softness of the plaster and rocks. Analysis of several of these bullets sets the shooting dates as not earlier than ca. 1900 as they are mostly copper-jacketed.

The Hildalgo County Land Office shows that the Santa Anita belonged to Manuel Gomez in 1911. Local legend has it that the wel1 was a waystop on the old road from Sal Del Rey to Guerrero and the only source of potable water for many miles around.

51.40 Tenneco H-17: Collapsed Brick Structure. This structure was located from a helicopter in the Phase I survey and was classed as a potential historic site. Our ground survey showed it to have been a circular structure, lined with lime. It was probably a cistern used 
This page has been

redacted because it

contains restricted

information. 
This page has been

redacted because it

contains restricted

information. 
This page has been

redacted because it

contains restricted

information. 


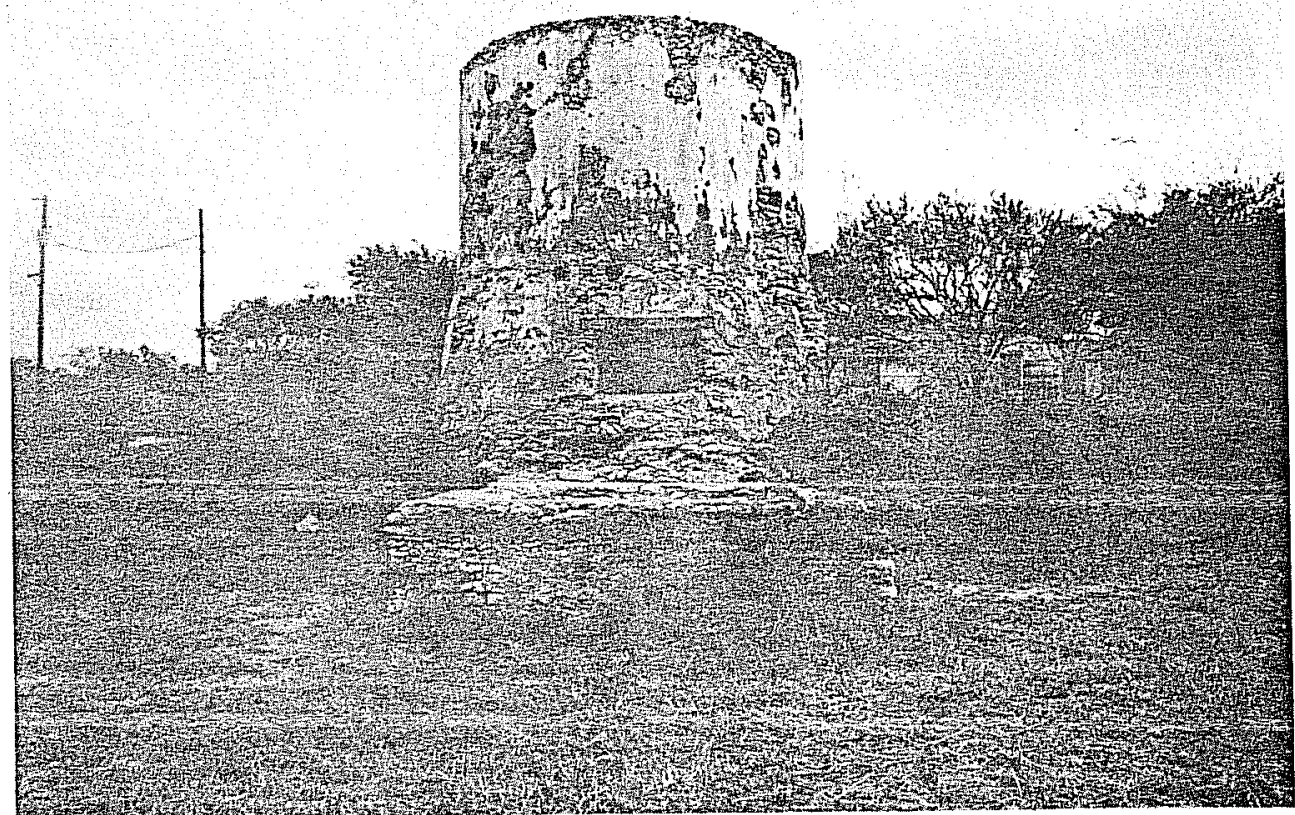

a

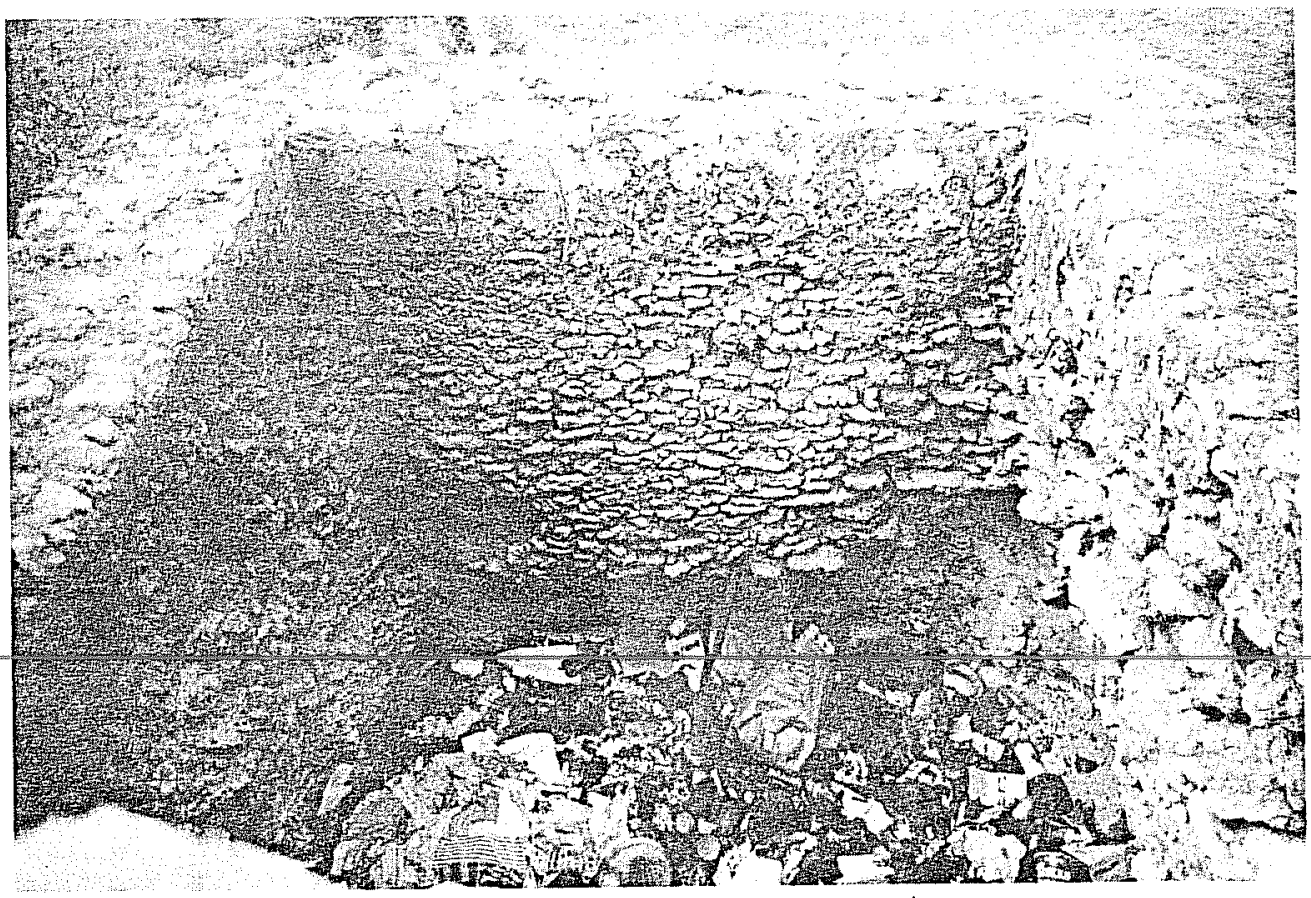

b

Figure 4. Views of Historic Well, MP 42.15. a, tower located on the north side of well; b, detail of well construction, looking south from tower. 

as a water stop on the Southern Pacific Railroad, which is 300 meters west. The site has become something of a dump with ca. 1920 or later garbage. Bricks used for construction were marked "BUTLER" and "ELGIN." with a third type unmarked. The site is not believed to be historically significant.

56.00 Tenneco A-40: Light Lithic Scatter. Three chert flakes were found in the ROW in a depressed, faintly visible watercourse. Sand had been washed or blown out down to the underlying Pleistocene clay. The flakes prove aboriginal presence somewhere in the vicinity at some time. However, they were the first prehistoric artifacts found in the initial 56 miles of intensive survey. There is the possibility that when pipeline trenches are dug through this old watercourse a prehistoric site may be found.

65.40 Laguna Salada (not to be confused with another Laguna Salada at MP 82.70). The ROW passes through the west edge of this large depression, which is presently dry and used as the Encino City Dump. Nothing. was found in the ROW nor in a survey of the entire laguna. Our map studies had suggested that it was a high potential site area.

73.59 High Potential Archaeological Area. A series of high sand dunes crosses

to this area from the southeast to northwest, with some of the dunes being

75.43 $75 \mathrm{ft}$ higher than the surrounding area. They would have provided excellent high overlook camp or observation sites. However, our predictions, based on topographic map assessments, were wrong again and nothing was found.

76.90 High Potential Archaeological Area. This is a depression which had water standing even though drought conditions prevailed at the time of the survey. Much to our surprise, and again contrary to our expectations, nothing was found.

82.00 Tenneco A-8, A-9: Potential Archaeological Area. This area was identito fied in the Phase I survey because Palo Blanco and Baluarte Creeks cross

84.00 the ROW near the Laguna Salada, which is a proven archaeological resource (sites 41 BK 3-4 were documented there during Phase I). Nothing was found despite excellent ground visibility due to drought in the area.

87.46 Tenneco A-41: Los 01mos Creek Potential Archaeological Site. Collectors in Falfurrias stated that they used to find artifacts along Los olmos creek. We examined 1.2 miles of the creek alongside the pipeline. Two chert flakes and a potsherd were found in the ROW in the south bank of the creek. Shovel tests indicated they were either thrown up when the pipeline was dug or were possibly derived from somewhere uphill in an area now covered by a dense cornfield. We recommend that an archaeologist be present when the pipeline trench is cut through this area.

92.00 Paisano Creek was too heavily vegetated in Phase I to permit survey. Visibility was good this time because of drought conditions. Nothing was found. 


\begin{abstract}
95.50 Tenneco A-42: Big Lake Lithic Scatter. A small amount of 1 ithic debitage is exposed in a road intersection 0.1 miles west of the pipeline. The camp sites were apparently very close to the lake edges as nothing was found within the ROW.
\end{abstract}

103.50 Derramadero de Machos Creek was not checked in the Phase I survey and, in fact, could not be found. This time, it was clearly visible and was flanked by rolling sand hills; these appeared to be a high potential area. However, nothing was found.

106.00 Escondido Creek. Nothing was found.

111.00 Santa Gertrudis Creek. Major creek with permanent water. Nothing was found.

Between Santa Gertrudis Creek and San Fernando Creek, the terrain changes from rolling sand dune hills to a much flatter and more stable terrain. From San Fernando Creek to the Nueces River the soil contains more silts and clays, and the level, fertile plain is almost one continuous maize field. The pipeline could be located only at road, and some creek, crossings. Despite our best efforts, this stretch can still be described as only poorly surveyed.

118.30 Tenneco A-43: San Fernando Creek. Hester (1973) reported two burials in the south bank of San Fernando creek at site $41 \mathrm{KL} 54$, approximately 2.6 miles downstream (east) from the pipeline crossing. Two other sites (41 KL 55-56) were recorded farther downstream. Hester (ibid.) attributed the artifact assemblage to the Late Prehistoric era. These sites were discovered after a channel improvement project by the U.S. Corps of Engineers had exposed them. We observed heavy silting of the stream and its banks at the pipeline crossing.

126.00 Pintas creek. The creek is badly silted with no gently sloping banks. Nothing was found.

132.24 Tenneco A-44: Agua Dulce Creek. The creek banks are an impenetrable jungle and no survey will be possible until the brush is cleared.

133.40 Tenneco A-45: Banquete Creek Archaeological Zone (Fig. 6). At MP to 133.4 the pipeline passes 0.17 miles west of the Banquete Cemetery, 134.15 crosses Highway 44 at MP 133.85 and crosses Banquete creek at MP

134.15. Between the cemetery and the highway, the pipeline comes within 0.05 miles of the known limits of $41 \mathrm{NU} 63$, a Late Archaic/ Late Prehistoric site that has been nominated to the National Register of Historic Places (Black 1978). The site was found and briefly tested in 1976 by the Center as part of the planning process for a proposed sewer treatment plant survey; the plant was relocated to protect this important site. Test pits dug to depths of $80 \mathrm{~cm}$ were rich in archaeological materials (Black 1978). Over 150 x 50 meters of intensive debitage scatter was visible in June 1978, recently uncovered by the combination of maize cultivation and sheet wash erosion of the site. We were unable to determine the westward 
This page has been

redacted because it

contains restricted

information. 
(toward the pipeline) limits of the si-te because an impenetrable growth of maize covers the ground as it did in Black's original 1976 survey. It was not even possible to locate the pipeline ROW because of the maize cover. Further survey and limited testing may be necessary to protect this valuable archaeological site.

134.15 Tenneco A-46: Prehistoric Archaeological Site and Potential Zone (Fig. 6). The pipeline crosses Banquete Creek north of State Highway 44 in an area where the creek is not well defined. This area was completely obscured by maize and it was not possible to determine the ROW boundaries. Farther north $(0.8$ miles from Highway 44 and 0.4 miles from the pipeline) site $41 \mathrm{NU} 170$ was found on the west bank. An area $15 \times 5$ meters covered with chert debitage has been recently exposed by maize cultivation and erosion. The site is assigned to the Late Prehistoric era based on the presence of a Perdiz arrow point. Two more freshly exposed lithic scatters were observed on the west bank within 0.5 miles of $41 \mathrm{NU} 170$, indicating heavy aboriginal use of the area. A high probability exists for archaeological sites at the pipeline crossing. It is recommended that an intensive surface survey and limited testing be conducted at a time when the field is fallow and the ROW can be determined.

140.50 Tenneco A-16, A-17. This area was listed in the Phase 1 survey as a to potential lithic procurement area, based on helicopter observation

142.60 and map studies. This proved to be true, as Uvalde Gravels (chert) were found along the high ridge (elevation $75 \mathrm{ft} \mathrm{msl)}$ ) that the pipeline crosses at MP 140.9 .

141.08 Tenneco A-47 (41 NU 171): Prehistoric Site (Fig. 7). A camp and knapping station were found on this ridge 0.4 miles NW of MP 141.08 . Heavy lithic scatter and burned sandstone rocks covered a $20 \times 25$ meter area. No diagnostics were found. (A local man has collected artifacts from the site for 25 years according to our Tenneco guide.) The cores and broken bifaces recovered indicate the Archaic time period for site occupation. Shovel tests revealed only two to three $\mathrm{cm}$ depth to the site. No further action is recommended.

Three other small lithic scatters were found northwest along this ridge, and one could be attributed to the Late Prehistoric period based on the recovery of a potsherd. The ROW contained raw lithics (Uvalde Gravels) only, and the extensive sand and gravel mining from MP 141.5 to 142.6 (the Nueces River) has effectively destroyed any archaeological traces. Nothing was found in the $300 \times 800 \mathrm{ft}$ Nueces River crossing work area. No further action is required.

143.95 Tenneco A-18 (41 SP 111) was revisited. It is on the high ridge (50 ft ms1) 1.5 miles NE of the present Nueces River channel. More Tithic material was found spread over a larger area, but again no diagnostics were recovered. Debitage extended into the easternmost of three pipelines, but, when this pipeline was walked back to the 
This page has been

redacted because it

contains restricted

information. 
nearest fence, we found that it belonged to Natural Gas Pipeline of America, not Tenneco. Therefore no further action is required of Tenneco, and A-18 (Hester 1979:Table 1) can be changed to priority 3 .

153.54 Tenneco A-26: Chiltipin Creek. Listed as a sensitive archaeological zone in the 1977 survey, the area was too heavily covered with grass and brush at that time to conduct an intelligent survey. This time the ground cover was much scantier, and a thorough search of the ROW produced no archaeological material. No further action is required.

164.00 Tenneco A-27 (41 SP 110). This area on the west bank of the Aransas River was rechecked, but erosion of the sheer bank has wiped out all traces of the site. No further action is required.

164.82 Tenneco A-28: the Aransas River Archaeological Zone. This zone and the $250 \times 300 \mathrm{ft}$ work area were carefully checked. Nothing was found. No further action is recommended.

167.00 Sous Creek was observed to have no archaeological potential in the 1977 Tenneco survey, and, while ground visibility was much better on this survey, nothing was found. No further action is required.

168.00 Devil's Run Creek was also barren of artifactual materials. No further action is recommended.

179.14 Tenneco A-29: Medio Creek, and its $200 \times 600 \mathrm{ft}$ work area and to Tenneco A-30: B Banco Creek, and its $200 \times 600 \mathrm{ft}$ work area were

179.40 carefully surveyed. Both map studies and the actual terrain indicate an ideal aboriginal camp situation between the two creeks. Nothing was found and no further action is recommended.

184.19 Tenneco A-48 (41 RF 16): West Fork of Melon Creek (Fig. 8). A site was found in the east bank of this creek that originates in Ninemile Flat, a dry lake. The site is 0.18 miles south of the Tenneco ROW and is in the northern edge of another oil company's ROW that parallels the Tenneco line. Pipeline construction and recent erosion have removed the topsoil down to a yellow clay, and the debitage, 2.5 meters in diameter, is exposed in a circular area. A single exhausted core was the apparent source of all the debitage produced. A crude concave scraper and lipped flakes indicate artifact manufacturing as the function of the site. A1l debitage was collected and analyzed in the laboratory. The site was completely deflated and no further action is required. It is interesting, however, because of the insight it can shed on the problem of finding prehistoric sites in this area of the Gulf Coastal Plain. The site was only recently exposed by the combination of pipeline earth-moving and erosion and would have perhaps disappeared downstream in the next heavy rain.

189.90 Tenneco H-44: $0^{\prime}$ Connor Line Shack. Investigation as to possible historical value was recommended by Hester (1979). The dipping 
This page has been

redacted because it

contains restricted

information. 
tanks, windmill and loading pens are still used for cattle management, but the cowboys no longer use this line shack. An inspection of the artifacts revealed nothing older than the past 30 to 40 years. It is not considered to be of historical importance.

191.58 Tenneco A-49: Western Edge of Sharps Lake (Fig; 9). An eroding road and sand dunes traversed by the ROW produced scattered lithic debitage over a considerable area. A specific site location could not be pinpointed, and it is assumed that it is probably buried. A testing program involving only two or three $1-\mathrm{m}^{2}$ units is recommended to attempt to locate the buried site.

192.70 Tenneco A-36 (41 RF 12): Sharps Lake Prehistoric Site (Fig. 9). (Note: We do not have too much confidence in the exact Tenneco MP mileage because of map scale error and the distance from another known MP. The site was reported as MP 194.66 in the Phase I survey [Hester 1979]. However, Tenneco has just completed a survey for the new pipeline and one of the survey markers is in the approximate center of the site.)

A man-altered or man-made ditch enters Sharps Lake just at the point where the pipeline crosses the lake boundary from the northeast. Tenneco has built a wooden bridge with concrete supports across this ditch, and the bridge is with in the site (Fig. 10). Lithic material is exposed across the pipeline ROW in both banks of the ditch and for 15 meters northeast by 45 meters southwest along the pipeline. Far more material was exposed on this survey than on the 1977 survey, including large dart point midsections. The dart point sections indicate either Archaic or, more probably, Paleo-Indian occupation, based only on the size and apparent collateral flaking observed on the specimens. Everything was left in situ as Mr. Leo Welder, the landowner, was most vehement in his objections to carrying out the testing excavations originally planned for the site during Phase II. This is by far the most important prehistoric site found in the entire survey, and it should be adequately tested before any more of it is destroyed by construction activities. The only alternative to excavation would appear to be a lengthy detour of the new pipeline of approximately 2.1 miles around the northwest end of Sharps Lake.

199.98 Tenneco A-31: San Antonio River. The $300 \times 800 \mathrm{ft}$ work area was not checked on the west bank because of extreme difficulty in securing access. We were told that someone shot up a tractor here last fall and the Tenneco locks have now been removed. However, based on the 1977 field notes, we suspect that the low flood plain on the west side would not have revealed any sites because of heavy alluvial deposition. The high-banked east side of the river was checked and nothing was found.

200.43 Tenneco H-50 (41 VT 65): the De La Garza Homestead (Fig. 11). A tumbled-down chimney was reported during helicopter observation in the Phase I survey, and there was a recommendation for recording the site. 
This page has been

redacted because it

contains restricted

information. 

This page has been

redacted because it

contains restricted

information. 
Someone has since hauled the chimney bricks away, but the sub-chimney foundation was located. It is 0.1 miles southeast of the Tenneco ROW and on the east edge of another oil company's ROW, 0.43 miles from where it crosses the San Antonio River. The homestead sat on top a steep bluff at an elevation of $75 \mathrm{ft} \mathrm{msl}$. The site overlooks a gulley containing an intermittent stream; water was standing at the time of survey.. Both historic and prehistoric materials were exposed in a two meter diameter ant bed four meters east of the chimney. A .32 rimfire cartridge case, square nails, scrap iron pieces, a buckle, glass, a historic potsherd (dated by Anne Fox of the Center as ca. 1860 and as of Ohio origin), and a Mexican potsherd of uncertain date made up the historic inventory. Al1 items were collected from the exposures in the ant bed. Four interior knapping flakes were also found in the ant bed, indicating an aboriginal presence at this site. The area has been so thoroughly disturbed that it may have no further historical or archaeological value. Interviews with memters of the De La Garza family living in the area and a check of the nearby cemetery are probably the best sources for any further investigation.

208.00 Tenneco A-32 (4T VT 64), reported in the Phase I survey, is rapidly being destroyed by an oil well that has appeared since the 1977 survey.

211.28 Tenneco A-35: the Guadalupe River Crossing. The $300 \times 800 \mathrm{ft}$ and $250 \times 800 \mathrm{ft}$ work areas were adequately covered in the Phase I survey. The meanders of the Guadalupe River and frequent flooding have covered up all surface indications of sites. Only some kind of boring operation, or the actual digging of the pipeline trench, might locate archaeological sites in this area.

214.09 The pipeline ROW from the high east bank of the Guadalupe River to station 9 is in an extensively cultivated field beyond MP 213, and nothing was found.

\section{SUMMARY OF SURVEY RESULTS}

Table 1 summarizes, in numerical sequence, the historic and prehistoric sites examined during Phase II field work. 
TABLE 1. PHASE II PREHISTORIC AND HISTORIC SITES ALONG THE PROPOSED PIPELINE ROUTE

Prehistoric Sites

\begin{tabular}{|c|c|c|c|c|}
\hline Site Number & Priority & Description & $\begin{array}{l}\text { Milepost } \\
\text { Number } \\
\end{array}$ & $\begin{array}{c}\text { Distance } \\
\text { from Pipeline } \\
\text { (Miles) }\end{array}$ \\
\hline $\begin{array}{l}\text { Hidalgo County } \\
\qquad A-40\end{array}$ & 2 & lithic scatter & 56.00 & intersects \\
\hline $\begin{array}{c}\text { Brooks County } \\
\text { A-41 }\end{array}$ & 2 & $\begin{array}{l}\text { potential archaeo- } \\
\text { logical site }\end{array}$ & 87.46 & intersects \\
\hline $\begin{array}{c}\text { Jim Wells County } \\
A-42\end{array}$ & 3 & lithic scatter & 95.50 & 0.7 \\
\hline $\begin{array}{c}\text { Kleberg County } \\
A-43\end{array}$ & 3 & prehistoric burials & 118.30 & 2.6 \\
\hline $\begin{array}{l}\text { Nueces County } \\
\qquad \begin{array}{c}A-44 \\
A-45\end{array}\end{array}$ & 2 & $\begin{array}{l}\text { potential site } \\
\text { potential damage to } \\
\text { National Register } \\
\text { site } 41 \text { NU } 63\end{array}$ & $\begin{array}{l}132.24 \\
133.40\end{array}$ & $\begin{array}{l}\text { intersects } \\
\text { possible } \\
\text { intersect }\end{array}$ \\
\hline $\begin{array}{l}A-46 \\
A-47\end{array}$ & $\begin{array}{l}2 \\
3 \\
3\end{array}$ & $\begin{array}{l}\text { potential zone } \\
\text { prehistoric site } \\
\text { prehistoric camp }\end{array}$ & $\begin{array}{l}134.15 \\
134.15 \\
141.08\end{array}$ & $\begin{array}{l}\text { intersects } \\
0.4 \\
0.4\end{array}$ \\
\hline $\begin{array}{l}\text { San Patricio County } \\
\text { A-18 }\end{array}$ & 3 & 41 SP 111 downgraded & 143.95 & 0.1 \\
\hline $\begin{array}{l}\text { Refugio County } \\
\text { A-48 } \\
A-49\end{array}$ & $\begin{array}{l}3 \\
2\end{array}$ & $\begin{array}{l}\text { prehistoric site } \\
\text { wide lithic scatter }\end{array}$ & $\begin{array}{l}184.19 \\
191.58\end{array}$ & $\begin{array}{l}0.18 \\
\text { intersects }\end{array}$ \\
\hline
\end{tabular}

Historic Sites

Site Number

H-53 Santa Anita Ranch, early hand dug-well and tower (Hidalgo County).

H-44 0'Connor Line Shack (1isted as possible Welder homestead). The structure is too recent to be of historical interest and may be eliminated (Refugio County).

$\begin{array}{llll}\text { H-50 De La Garza Homestead (41 VT 65, Victoria County) } & 200.43^{*} & 0.10\end{array}$ 


\section{RECOMMENDATIONS}

Tenneco Sites A-38, 39, 40,41, 44 and 46 are either lithic scatters in the right-of-way or areas of archaeological potential that could not be surveyed because of brush or crop cover. Without subsurface testing, it is impossible to know how many archaeological resources are missed in a survey such as the one we have just conducted. It is therefore recommended that this survey be continued on the above sites in conjunction with the clearance prior to pipeline construction.

At Tenneco A-45 there is the threat of partial destruction to National Register site $41 \mathrm{NU}$ 63. The right-of-way is presently covered with dense maize. It is recommended that limited testing be accomplished when the field lies fallow, or just prior to construction, to determine whether $41 \mathrm{NU} 63$ extends into the right-of-way.

Tenneco A-49 is part of the Sharps Lake archaeological complex. Limited testing is recommended in the right-of-way. 


\section{REFERENCES CITED}

Black, S. L.

1978 Archaeological Investigations at the Banquete Bend Site (41 NU 63), Nueces County, Texas. Center for Archaeological Research. The university of Texas at San Antonio, Archaeological Survey Report 63.

Hester, T. R.

1973 Notes on an Archaeological Site in Kleberg County, Texas. Newsletter, Houston Archaeological Society 41:2-6.

Hester, T. R., Editor

1979 A Preliminary Archaeological and Historical Assessment of the Proposed Tenneco Pipeline: Hidalgo to Victoria Counties, Texas. Center for Archaeological Research. The University of Texas at San Antonio, Archaeological Survey Report 51.

Mallouf, R. J., B. J. Baskin and K. L. Killen

1977 A Predictive Assessment of Cultural Resources in Hidalgo and Willacy Counties, Texas. Texas Historical Commission, Office of the State Archeologist, Survey Report 23.

Mueller, J.W.

1974 The Use of Sampling in Archaeological Survey. Society for American Archaeology, Memoir 8. 